\title{
Changes to Physical Properties of the Cell Wall and Polyuronides in Response to Heat Treatment of 'Fuyu' Persimmon that Alleviate Chilling Injury
}

\author{
Allan B. Woolf, Elspeth A. MacRae, Karen J. Spooner, and Robert J. Redgwell \\ The Horticulture \& Food Research Institute of New Zealand, Mt Albert Research Centre, Private Bag \\ 92169, Auckland, New Zealand.
}

\begin{abstract}
AddTIOnal Index words. Diospyros kaki, fruit ripening, postharvest physiology, shelf life, fruit quality
ABstract. Modifications to solubilized cell wall polyuronides of sweet persimmon (Diospyros kaki L. 'Fuyu') were examined during development of chilling injury (CI) during storage and in response to heat treatments that alleviated $\mathrm{CI}$. Storage at $0{ }^{\circ} \mathrm{C}$ caused the solubilization of a polyuronide fraction that possessed a higher average molecular mass than polyuronide solubilized during normal ripening. The viscosity of this fraction was 30-times that of normally ripened fruit. Fruit heat-treated before or following storage contained a soluble polyuronide fraction with a markedly lower average molecular mass and decreased viscosity than in chilling injured fruit. Heat treatment also impeded an increase in viscosity of the cell wall material if applied before storage. CI (gelling) was related to the release of polyuronide from the cell wall during storage and its lack of subsequent degradation. Heat treatments retarded polyuronide release but promoted degradation of solubilized polyuronides.
\end{abstract}

'Fuyu' persimmons can develop chilling injury (CI) when stored for more than 4 weeks at $0^{\circ} \mathrm{C}$ (MacRae, 1987). Symptoms associated with injury are significant reduction in fruit firmness, off-flavors, increased ethylene production on removal from storage, and major textural faults, such as mealiness (loss of free juice) and, in more severe cases, browning of flesh and skin, and formation of a firm gel. Development of CI symptoms (gel formation) in individual fruit during storage has recently been monitored using magnetic resonance imaging (MRI), a noninvasive technology that provides spatial information about the distribution and mobility of aqueous protons within a sample over time (Clark and Forbes, 1994; Clark and MacFall, 1996). Results from MRI investigation implied that major changes in solution chemistry occurred as CI developed (Clark and MacFall, 1996).

Grant et al. (1992) examined cell wall metabolism of 'Fuyu' persimmons and found that chilling-injured fruit passed through the normal ripening changes more rapidly than those without storage. However, in injured fruit, the solubilized polymers had a higher molecular mass and contained a higher proportion of neutral sugars than normally ripened fruit. Neutral sugars, characteristically associated with hemicelluloses, also were lost from the insoluble cell wall material (CWM) in injured fruit but not in normally ripened fruit, and data suggested that there was a net increase in the insoluble CWM during storage.

Prestorage heat treatments (HTs) have alleviated $\mathrm{CI}$ in a number of crops including persimmons. Woolf et al. (1997) demonstrated that dry air HTs of $47^{\circ} \mathrm{C}$ for 0.5 to $3 \mathrm{~h}$ significantly reduced $\mathrm{CI}$ in 'Fuyu' persimmons stored at $0^{\circ} \mathrm{C}$ relative to nonheated fruit. Associated with HTs were increases in fruit firmness, titratable acidity, color ( $\mathrm{L}$ value, hue, and chroma), and reduction of the ethylene burst $1 \mathrm{~d}$ after removal from storage.

Klein et al. (1990) showed an inverse correlation between solubilization of pectin and retention of firmness in response to a hot-air treatment of $38^{\circ} \mathrm{C}$ for $4 \mathrm{~d}$ in stored apple. Little work has

Received for publication 26 Aug. 1996. Accepted for publication 14 Apr. 1997. We acknowledge the Foundation for Science Research and Technology (CO6621), and $\mathrm{ABW}$ was funded by the Agricultural and Marketing Research and Development Trust, Project No: 1171/1178. The cost of publishing this paper was defrayed in part by the payment of page charges. Under postal regulations, this paper therefore must be hereby marked advertisement solely to indicate this fact. been performed examining the effects of HTs on cell wall composition of cool-stored fruit, and, to our knowledge, no research has been performed on fruit that are susceptible to CI.

In persimmons, the reduction of CI by HTs (Woolf et al., 1997) provides a means to study heat effects on the biochemistry of fruit softening and CI development and a tool to re-examine which components of cell wall modification are associated with injury development. In this paper we report a study of the comparative properties of the cell wall and solubilized cell wall polyuronides from normally ripened fruit, chilling-injured fruit, and fruit heattreated before and after storage.

\section{Materials and Methods}

Fruit. Sweet persimmon fruit ('Fuyu') were harvested in late fall (May), and 12 fruit were randomly assigned to each treatment. The following day, fruit quality characteristics were assessed for the "harvest" sample $\left(\mathrm{T}_{0}\right)$, as described in Grant et al. (1992) and MacRae (1987), and the treatments commenced.

TREATMENTS AND SAMPLING. Based on our previous work (Grant et al., 1992; Woolf et al., 1997), we applied four treatments. Seven times were selected for fruit assessments and tissue sampling for subsequent cell wall isolation (see below). Treatments and sampling points are shown in diagrammatic form in Fig. 1 and details of methodology follow:

( $\left.T_{0}\right) \quad$ Harvest (initial maturity/start point)

(20-R) Ripe fruit-held at $20^{\circ} \mathrm{C}$ for $14 \mathrm{~d}$ until eating ripe (normal ripening)

Stored fruit - held at $0{ }^{\circ} \mathrm{C}$ for 6 weeks (CI induced but not yet evident)

(S-20) Stored, injured fruit-held at $20^{\circ} \mathrm{C}$ for $3 \mathrm{~d}$ after storage at $0{ }^{\circ} \mathrm{C}$ for 6 weeks [CI (gelling and mealiness) developed]

$(H-S) \quad$ Heat-treated, stored fruit-subjected to a $47^{\circ} \mathrm{C}, 0.5-\mathrm{h}$ dry air $\mathrm{HT}$, then held in storage at $0{ }^{\circ} \mathrm{C}$ for 6 weeks (pre-storage HT inhibits CI) 
$(H-S-20)$ Heat-treated and ripened fruit-held at $20^{\circ} \mathrm{C}$ for $3 \mathrm{~d}$ after removal from storage at $0{ }^{\circ} \mathrm{C}$ for 6 weeks (CI inhibited, low levels now evident)

$(S-H-20)$ Stored and heat-treated fruit-stored at $0{ }^{\circ} \mathrm{C}$ for 6 weeks, heat-treated, and held a further $3 \mathrm{~d}$ at $20^{\circ} \mathrm{C}$ (CI induced during storage, then heat-treated for comparison to effect of prestorage HT).

Heat treatment. Dry air HTs were performed in 147-L chambers as described by Woolf et al. (1995). Air and internal fruit temperatures were measured and recorded every 2 min using data loggers (model 1206; Grant, Cambridge, U.K.). Internal temperature was measured by inserting a thermistor temperature probe (model CM-UU-V5-1; Grant) into the center of the fruit. The duration of HT $(0.5 \mathrm{~h})$ was taken from the time at which the internal fruit temperature reached the target temperature $(2 \mathrm{~h}$ from the time of heating).

For the $S-H-20$ treatment (stored, then heat-treated), fruit were removed from $0^{\circ} \mathrm{C}$ storage, rapidly warmed to $20^{\circ} \mathrm{C}$ using a fan $(2 \mathrm{~h})$, then heat-treated in the same manner as previously described, and held for $3 \mathrm{~d}$ at $20^{\circ} \mathrm{C}$.

STORAGE. Fruit were packed into commercial cardboard trays with plastic pocketpacks and held at $0^{\circ} \mathrm{C}$ in open trays overnight to rapidly reduce temperature $\left(3 \mathrm{~h}\right.$ to achieve $\left.<2{ }^{\circ} \mathrm{C}\right)$. Then, lids were replaced.

Fruit assessments. Fresh mass of 12 fruit per treatment was recorded at harvest and again when destructively sampled, and mass loss was calculated as the percentage loss in mass compared to harvest values. The following assessments were performed as originally described (MacRae, 1987), with slight modifications (Woolf et. al., 1997). Soluble solids concentration (SSC) was determined by expressing juice from a longitudinal segment onto an electronic $0 \%$ to $20 \%$ refractometer (model PR-1; Atago, Tokyo, Japan). Three averaged color readings per fruit were taken around the equator using a chroma meter with a D65 light source (II Reflectance; Minolta Camera Co., Osaka, Japan). Color was expressed as L value (color intensity changing from light to dark), chroma (intensity of color), and hue angle (actual color) (McGuire, 1992).

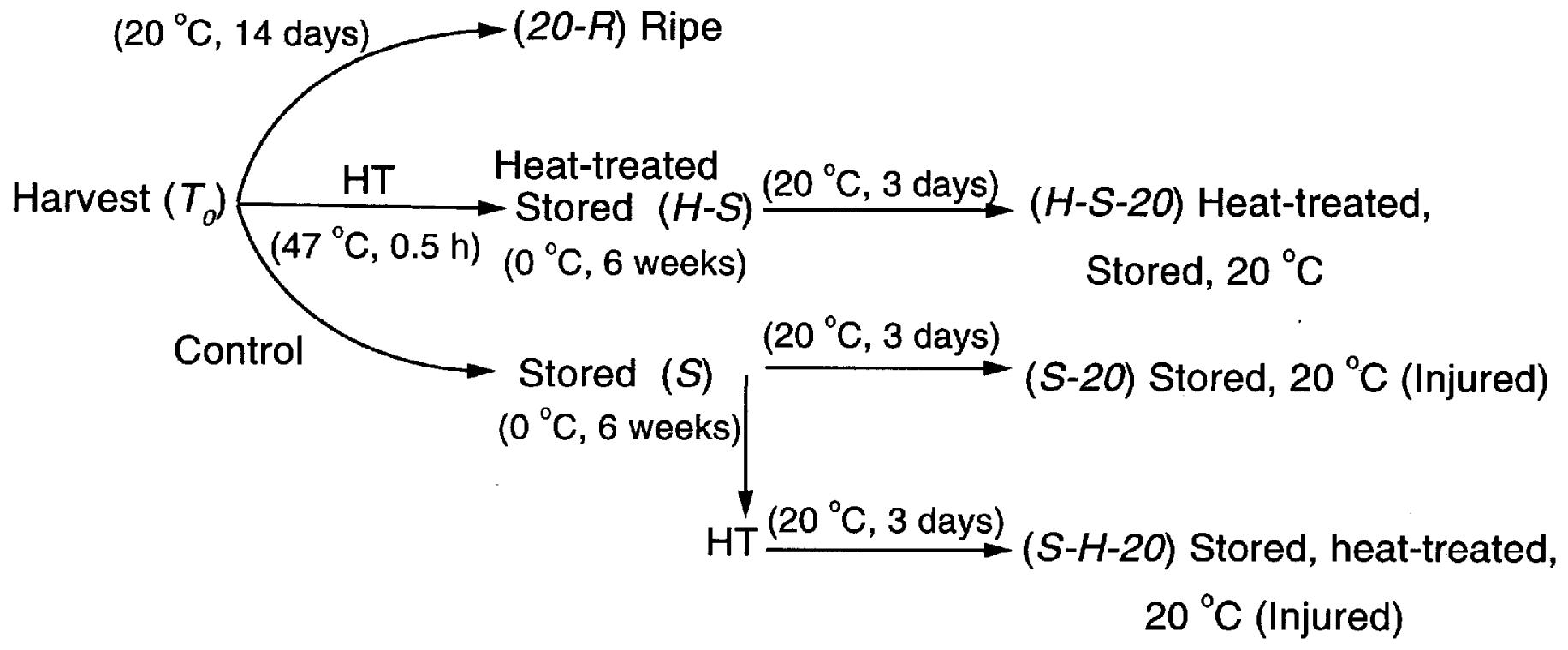

Fig. 1. Treatment scenarios and sampling times
Four equatorial fruit firmness measurements were made using an hand-operated penetrometer $(8 \mathrm{~mm}$ diameter head, conical shape) (Imada Seisakusyo, Toyohashi, Japan). Estimates of CI (gelling and mealiness (loss of juiciness) were made on a subjective scale of $0=$ none to $5=$ severe, as previously described (MacRae, 1987). An additional measure of tissue texture was performed using an universal testing machine (model 6301; Instron, Canton, Mass.). A 7-mm-thick equatorial slice was taken from each of 12 fruit, from which a disk ( $15 \mathrm{~mm}$ in diameter) of tissue ( 1.4 to $1.6 \mathrm{~g}$ ) was removed by corkborer. The 12 disks (one from each fruit) were placed in a Kramer shear cell (Instron), and the maximum force was recorded (Harker et. al., 1996). This procedure was repeated four times.

Cell wall isolation. Twelve fruit were separated into three, four-fruit replicates. The cortex was removed, flash frozen in liquid $\mathrm{N}$, and stored at $-80^{\circ} \mathrm{C}$ until processed. CWM and solubilized polyuronides were isolated from a 2 phenol : 1 acetic acid :1 water (w:v:v) (PAW) suspension of the cryomilled tissue as previously described (Grant et al., 1992). PAW effectively inactivates enzyme activity and dissolves those polyuronides that have been solubilized by in vivo processes. The fractions were assessed with regard to viscosity (PAW-soluble and CWM), swelling (CWM), and molecular mass profile (PAW-soluble polyuronides). Measurement of viscosity and swelling were performed as previously described (Grant et al., 1992; Redgwell et al., 1992). Molecular mass profiles of the solubilized polyuronides (PAW-soluble fraction) were determined on a Sepharose CL- 2 B column $(2.5 \times 97$ $\mathrm{cm}$ ), equilibrated in $0.05 \mathrm{~m} \mathrm{Na}$ acetate buffer ( $\mathrm{pH}$ 6.0) containing $125 \mathrm{~mm} \mathrm{NaCl}$. Fractions ( $\approx 8 \mathrm{mg}$ ) were dissolved in $1 \mathrm{~mL}$ of the same buffer and eluted through the column $\left(10 \mathrm{~mL} \cdot \mathrm{h}^{-1}\right)$; fractions (4 $\mathrm{mL}$ ) were assayed for uronic acid according to Blumenkrantz and Asboe-Hansen (1973). Neutral sugar composition of the PAW-soluble fractions was determined by GLC analysis of the alditol acetates following hydrolysis in $2 \mathrm{~m}$ TFA (Grant et al., 1992). Protein concentration was determined (Bradford, 1976).

\section{Results and Discussion}

Fruit CHARACTERISTICS. Fruit quality characteristics of 'Fuyu' persimmons at harvest $\left(T_{0}\right)$ were typical of those of commercial 
Table 1. Effect of ripening at $20^{\circ} \mathrm{C}(R)$, heat treatment at $47^{\circ} \mathrm{C}$ for $0.5 \mathrm{~h}(H)$, and storage at $0{ }^{\circ} \mathrm{C}$ for 6 weeks $(S)$ on fruit quality characteristics. Means \pm SE of 12 individual fruit. Letters correspond to treatments and sample points shown in Fig. 1.

\begin{tabular}{|c|c|c|c|c|c|c|c|c|c|c|c|c|c|c|c|}
\hline \multirow{2}{*}{$\begin{array}{l}\text { Fruit quality } \\
\text { characteristic }\end{array}$} & \multirow{2}{*}{$\begin{array}{l}\text { Treatment / } \\
\text { sampling time }\end{array}$} & \multicolumn{2}{|c|}{$T_{0}$} & \multicolumn{2}{|c|}{$20-R$} & \multicolumn{2}{|c|}{$S$} & \multicolumn{2}{|c|}{$H-S$} & \multicolumn{2}{|c|}{$S-20$} & \multicolumn{2}{|c|}{$S-H-20$} & \multicolumn{2}{|c|}{$H-S-20$} \\
\hline & & Mean & $\mathrm{SE}$ & Mean & $\mathrm{SE}$ & Mean & SE & Mean & $\mathrm{SE}$ & Mean & $\mathrm{SE}$ & Mean & $\mathrm{SE}$ & Mean & $\mathrm{SE}$ \\
\hline \multirow[t]{3}{*}{ Color } & $\mathrm{L}$ & 60.3 & 0.1 & 55.7 & 0.1 & 56.7 & 0.0 & 59.1 & 0.1 & 44.9 & 0.1 & 50.5 & 0.1 & 58.2 & 0.1 \\
\hline & Hue & 63.7 & 1.0 & 53.3 & 1.1 & 58.3 & 0.7 & 58.6 & 0.8 & 59.0 & 0.6 & 59.5 & 1.1 & 60.4 & 0.7 \\
\hline & Chroma & 64.6 & 1.1 & 63.1 & 1.1 & 63.4 & 0.7 & 66.8 & 0.4 & 34.3 & 1.1 & 47.7 & 1.2 & 62.5 & 1.0 \\
\hline \multirow[t]{2}{*}{ Firmness (N) } & Penetrometer & 59.4 & 2.0 & 28.6 & 2.9 & 42.3 & 2.0 & 59.5 & 2.0 & 10.4 & 0.5 & 13.0 & 1.0 & 35.7 & 3.9 \\
\hline & Instron & 770 & 6 & 258 & 20 & 452 & 19 & 737 & 16 & 69 & 1 & 132 & 9 & 376 & 31 \\
\hline $\operatorname{SSC}(\%)$ & & 15.3 & 0.7 & 15.6 & 0.7 & 14.6 & 0.6 & 15.3 & 0.6 & NA & & NA & & 16.1 & 0.8 \\
\hline Mass loss (\%) & & $\mathrm{NA}$ & & 7.3 & 0.6 & 3.1 & 0.8 & 2.3 & 0.1 & 3.2 & 0.2 & 4.9 & 0.2 & 4.2 & 0.2 \\
\hline
\end{tabular}

harvest maturity (Table 1). Following storage, the firmness of heat-treated fruit $(H-S)$ was equivalent to that of the harvest sample, while nonheat-treated fruit $(S)$ had softened significantly, although color of heated and nonheated fruit were similar (Table 1). Nonheat-treated fruit $(S)$ had a slightly greater water loss than heat-treated fruit $(H-S)$ and showed minor gelling and a moderate degree of mealiness, while heat-treated fruit had only slight mealiness (data not shown). These changes to fruit characteristics were similar to earlier results (Grant et. al., 1992; Woolf et. al., 1997).

Among the softened fruit, the lowest water loss was in the nonheated, injured fruit $(S-20)$, and the greatest amount was in normally ripened, nontreated fruit $(20-R)$ (Table 1$)$. The nonheated, stored fruit $(S-20)$ were the softest and least red (lowest Hue angle; Table 1), and they had the greatest degree of CI (average rating of 4.2 -almost complete gelling and mealiness). HT after storage ( $S$ $H$-20) modified these characteristics slightly, but the level of softness (Table 1) and injury (average rating of 3.9) remained similar to that of the nonheated fruit $(S-20)$. As found by Woolf et. al. (1997), HT before storage $(H-S-20)$ resulted in fruit with similar fruit firmness and color to that of normally ripened fruit (20-R), although some CI was still present (average rating of 2.2).

Characterization of SOLUBILIZED POL YURONIDES. As nonheated fruit ripened normally at $20^{\circ} \mathrm{C}\left(T_{0}\right.$, to $20-R$ ), there was a 10 -fold increase in the amount of polyuronide (uronic acid) solubilized (Table 2), but the viscosity remained similar to that at harvest. Comparing the size profiles between harvest and ripe fruit showed that the polyuronides were predominantly of moderate $(20-R)$ or low $\left(T_{0}\right)$ molecular mass (Fig. 2A). These results are consistent with those obtained in previous experiments (Grant et al., 1992).

Twice as much polyuronide was solubilized from the cell wall of nonheat-treated fruit $(S)$ during storage than from heat-treated fruit ( $H-S$; Table 2$)$. However, the pectin solubilized was at least 10 -fold more viscous than that from heat-treated fruit. In a previous study (Grant et al., 1992), the viscosity of the solubilized pectin
(PAW fraction) was not examined immediately on removal from storage. The greatly increased viscosity (Table 2) and large size of the pectin (Fig. 2B) that occurred in nonheat-treated fruit $(S)$ in this study was an early indication that fruit would develop CI when held at $20^{\circ} \mathrm{C}$. We speculate that these cell wall changes reflect a specific low-temperature response. Heat-treated fruit showed a more even spread of polyuronide sizes in response to storage.

Fruit with the greatest $\mathrm{CI}$ (nonheated; $S$-20; average rating of 4.2 ) had the greatest yield of soluble polyuronide. This yield was similar to that of normally ripened fruit $(20-R)$. Fruit sampled immediately after storage $(S)$ or fruit that had been heat-treated $(H$ $S-20 ; S-H-20$ ) had half the yield of soluble polyuronide than that of normally ripened fruit (Table 2). The yield of the PAW-soluble fraction increased $(S-H-20)$ from that immediately after storage and before a prestorage HT ( $S$, Table 2$)$, but the polyuronide quantity did not increase. This result showed that HT of potentially chilling-injured fruit specifically reduced further solubilization of pectin. The poststorage HT reduced the incidence of CI gelling only slightly (average rating of 3.9). However, this postharvest HT resulted in a 7 -fold decrease in viscosity of the PAW-soluble fraction compared with injured fruit ( $S-H-20 \mathrm{cf}$. $S-20$; Table 2 ). In comparison, fruit that had been heat-treated before storage $(H-S$ 20) showed a similar yield of polyuronide and viscosity to the fruit that were heat-treated after storage ( $S-H-20$; Table 2$)$ but had reduced CI symptoms (average rating of 2.2). The yield of the PAW-soluble fraction also was reduced in fruit heat-treated before storage ( $H-S-20$ vs. $S-H-20)$.

When polyuronide fractions of fruit held at $20^{\circ} \mathrm{C}$ for $3 \mathrm{~d}$ after storage were compared (Fig. $2 \mathrm{C}$ ), nonheated fruit $(S-20)$ had the greatest quantity of high molecular mass polyuronide, which was consistent with the high viscosity of this sample. This result confirms the earlier findings of Grant et al. (1992). In contrast, fruit that was heat-treated after storage $(S-H-20)$ had a less-high molecular mass polyuronide and more low molecular mass polyuronide. This result suggests that a key effect of HT was a

Table 2. Effect of ripening at $20^{\circ} \mathrm{C}(R)$, heat treatment at $47^{\circ} \mathrm{C}$ for $0.5 \mathrm{~h}(H)$, and storage at $0{ }^{\circ} \mathrm{C}$ for 6 weeks $(S)$ on cell wall characteristics. Means $\pm \mathrm{SE}$ of three replicates of four fruit combined. Letters correspond to treatments and sample points shown in Fig. 1.

\begin{tabular}{|c|c|c|c|c|c|c|c|c|c|c|c|c|c|c|c|}
\hline \multirow{2}{*}{$\begin{array}{l}\text { Call wall } \\
\text { characteristic }\end{array}$} & \multirow{2}{*}{$\begin{array}{l}\text { Treatment / } \\
\text { sampling time }\end{array}$} & \multicolumn{2}{|c|}{$T_{0}$} & \multicolumn{2}{|c|}{$20-R$} & \multicolumn{2}{|l|}{$S$} & \multicolumn{2}{|c|}{$H-S$} & \multicolumn{2}{|c|}{$S-20$} & \multicolumn{2}{|c|}{$S-H-20$} & \multicolumn{2}{|c|}{$H-S-20$} \\
\hline & & Mean & SE & Mean & SE & Mean & $\mathrm{SE}$ & Mean & $\overline{\mathrm{SE}}$ & Mean & SE & Mean & $\overline{S E}$ & Mean & SE \\
\hline Cell wall yield & CWM & 3.16 & 0.09 & 2.49 & 0.16 & 2.97 & 0.02 & 2.89 & 0.33 & 2.22 & 0.2 & 2.23 & 0.03 & 2.83 & $\overline{0.10}$ \\
\hline$(g / 200 g)^{2}$ & PAW & 0.19 & 0.01 & 0.86 & 0.08 & 0.30 & 0.02 & 0.22 & 0.03 & 0.71 & 0.05 & 0.56 & 0.05 & 0.40 & 0.03 \\
\hline $\begin{array}{l}\text { Uronic acid } \\
(\mathrm{mg} / 200 \mathrm{~g})\end{array}$ & PAW & 26.8 & & 218.4 & & 114.0 & & 51.5 & & 218.6 & & 109.0 & & 119.0 & \\
\hline Viscosity (cp) & $\begin{array}{l}\text { CWM } \\
\text { PAW }\end{array}$ & $\begin{array}{l}27.5 \\
61.7\end{array}$ & $\begin{array}{l}11.3 \\
33.7\end{array}$ & $\begin{array}{r}842 \\
36\end{array}$ & $\begin{array}{r}134 \\
4\end{array}$ & $\begin{array}{r}225 \\
1078\end{array}$ & $\begin{array}{l}60 \\
64\end{array}$ & $\begin{array}{r}100 \\
84\end{array}$ & $\begin{array}{l}60 \\
45\end{array}$ & $\begin{array}{l}667 \\
222\end{array}$ & $\begin{array}{l}72 \\
50\end{array}$ & $\begin{array}{r}543 \\
34\end{array}$ & $\begin{array}{r}161 \\
1\end{array}$ & $\begin{array}{r}110 \\
78\end{array}$ & $\begin{array}{l}30 \\
27\end{array}$ \\
\hline Swelling (cm) & CWM & 5.0 & 0.6 & 11.7 & 0.3 & 5.2 & 0.3 & 6.8 & 0.4 & 9.5 & 0.5 & 10.0 & 0.6 & 6.5 & 0.3 \\
\hline
\end{tabular}

${ }^{\mathrm{x}}$ Fresh mass basis. 
reduced solubilization of high molecular mass polyuronides and an increased degradation rate of those present before HT. Polyuronides solubilized from fruit heat-treated before storage $(H$ $S-20)$ showed a relatively even distribution of polyuronide sizes.

We examined the composition of the PAW-soluble fraction to
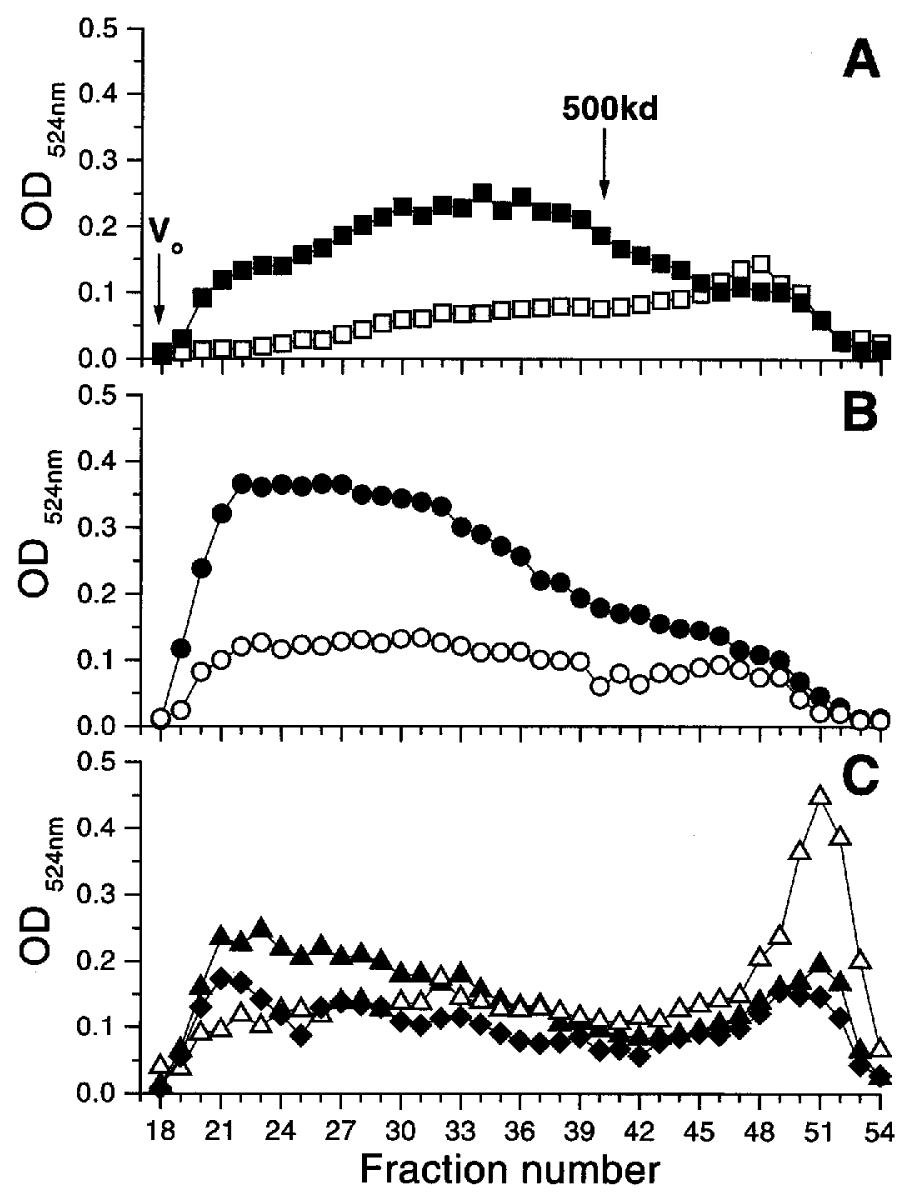

Fig. 2. Molecular mass profile of solubilized poluronide (PAW fraction). (A) Comparison of fruit at harvest $\left(T_{0} ; \square\right)$ and after normal ripening at $20^{\circ} \mathrm{C}(20-R$; D). (B) Comparison of fruit at the end of storage at $0^{\circ} \mathrm{C}$ with heat treatment before storage at $0^{\circ} \mathrm{C}(H-S ; O)$ or nonheated $(S ; O)$. (C) Comparison of fruit $3 \mathrm{~d}$ after removal from storage without heat treatment $(S-20 ; \mathbf{A})$ and with heat treatment either before storage $(H-S-20 ; D)$ or after storage $(S-H-20 ; \Delta) . \mathrm{V}_{\mathrm{o}}$ indicates the void volume and largest polymers, $500 \mathrm{kD}$ indicates the elution position of a blue dextran $500 \mathrm{kD}$ standard.

Table 3. Effect of ripening at $20^{\circ} \mathrm{C}(R)$, heat treatment at $47^{\circ} \mathrm{C}$ for $0.5 \mathrm{~h}(H)$, and storage at $0{ }^{\circ} \mathrm{C}$ for 6 weeks $(S)$ on chemical composition of the PAW-soluble fractions. Letters correspond to treatments and sample points shown in Fig. 1.

\begin{tabular}{|c|c|c|c|c|c|c|c|}
\hline \multirow{2}{*}{$\begin{array}{l}\text { Monosaccharide } \\
\text { composition (mol \%) }\end{array}$} & \multicolumn{7}{|c|}{ Treatment/sampling point } \\
\hline & $T_{0}$ & $20-R$ & $S$ & $H-S$ & $S-20$ & $S-H-20$ & $H-S-20$ \\
\hline$\overline{\text { Rhamnose }}$ & 3.3 & 6.8 & 3.8 & 3.3 & 9.6 & 11.8 & 8.3 \\
\hline Fucose & 0.4 & 1.1 & 0.6 & 0.9 & 1.0 & 0.9 & 0.5 \\
\hline Arabinose & 17.4 & 11.7 & 13.3 & 16.6 & 25.5 & 29.7 & 20.4 \\
\hline Xylose & 15.6 & 8.4 & 10.2 & 14.9 & 5.9 & 6.7 & 9.2 \\
\hline Mannose & 4.1 & $\mathrm{ND}^{z}$ & ND & 2.2 & ND & ND & ND \\
\hline Galactose & 29.2 & 15.7 & 18.3 & 22.6 & 14.6 & 18.7 & 17.8 \\
\hline Glucose & 4.4 & 9.4 & 6.0 & 5.9 & 7.3 & 7.5 & 8.4 \\
\hline Uronic acids & 25.4 & 47.8 & 47.7 & 33.6 & 37.1 & 25.1 & 34.8 \\
\hline Protein $(\% \mathrm{w} / \mathrm{w})$ & 15.2 & 5.1 & 4.8 & 7.5 & 9.6 & 17.1 & 13.4 \\
\hline Recovery (\%) & 64 & 55 & 78 & 73 & 84 & 88 & 90 \\
\hline
\end{tabular}

${ }_{\mathrm{zND}}=$ not detectable. ascertain whether the differences in viscosity were due solely to polymer size or also to differential composition (and therefore the presence of different polymers). The chemical composition of the PAW-soluble fraction (Table 3) showed a striking similarity between the neutral sugars of normally ripened fruit and that of fruit stored at $0{ }^{\circ} \mathrm{C}(20-R$ and $S)$. The dramatic increase in the viscosity of the PAW-soluble fraction in fruit following storage is, therefore, attributable to its molecular size, and not a difference in composition. The similarity in the composition of the PAWsoluble fractions of fruit at harvest $\left(T_{0}\right)$ and fruit stored at $0{ }^{\circ} \mathrm{C}$ after HT $(H-S)$ provides further support that the HT specifically prevents solubilizaion of polymers during storage, the only major difference being a lower protein content. However the results also indicate that protein content did not correlate with viscosity of the PAW-soluble fraction. HTs resulted in more protein solubilized with the PAW-soluble fraction when the fruit were soft, regardless of the timing of the HT.

The only marked difference in composition of the PAWsoluble fraction occurred in the chilling-injured fruit ( $\mathrm{S}-2 \mathrm{O}, \mathrm{S}-\mathrm{H}$ 20 , and $H-S-20)$ compared to non-injured fruit $\left(T_{0}, 20-R, S, H-S\right)$. In these fractions, there was an increased ratio of arabinose : xylose and glucose compared to all other fractions and a higher rhamnose content (Table 3). The difference was less marked in the PAWsoluble fraction from heat-treated then stored and ripened fruit $(H$ $S-20$ ), but this fruit also exhibited less injury. Curiously we were able to account for less of the PAW-soluble fraction composition in nonstored fruit (i.e., $T_{0}$ and $20-R$ ), and we are unable to explain this result. One possibility may be that there are more phenolics associated with the PAW-soluble fraction in these fruit than in stored fruit.

ChaRACTERIZATION OF THE PHYSICAL PROPERTIES OF THE CWM. During normal ripening ( $T_{0}$ to $20-R$ ), the cell wall yield decreased slightly while the viscosity of aqueous suspensions of CWM increased $\approx 25$-fold (Table 2 ). This was associated with a concurrent 2-fold increase in swelling of the CWM. These results are similar to those from earlier work where the viscosity of the CWM increased 20-fold during normal ripening (Grant et al., 1992). Swelling of the CWM and an increase in viscosity have also increased during ripening in kiwifruit [Actinidia deliciosa var deliciosa (A. Chev. C.F. Liang et A.R. Ferguson 'Hayward'] (Redgwell et al., 1992; Redgwell and Percy, 1992).

Yields of CWM were similar whether fruit had been heattreated before storage $(H-S)$ or nonheated $(S)$, but swelling and viscosity of the CWM differed markedly (Table 2). Immediately following storage, the CWM of nonheated fruit was twice as viscous as those from heat-treated fruit, but, unlike heat-treated fruit, swelling of the CWM was similar to that at harvest.

Although an increased yield of CWM was not found during storage of nonheat -treated fruit in these experiments (as reported in Grant et. al., 1992), the increase in viscosity of CWM compared to that at harvest also was found in the previous study. We examined whether water loss was able to explain this difference in results between the two studies (Table 2) but were unable to find an explanation for the discrep- 
ancy between the two sets of results, although the relative increase in viscosity of the CWM after storage compared to harvest is far greater in these experiments (10-fold) than in those of Grant et al. (1992) (2-fold), implying a greater solubilization of pectin or different cell wall characteristics in the fruit at harvest.

When these fruit were removed from storage and held at $20^{\circ} \mathrm{C}$ (Table 2), the yield of CWM decreased if the fruit were not heattreated before storage. Prestorage HT $(H-S-20)$ resulted in firmer fruit after storage and also resulted in a yield of CWM similar to that at harvest $\left(T_{0}\right)$ or after storage $(H-S)$.

The viscosity of the CWM did not increase during poststorage ripening if the fruit had been heat-treated before storage $(\mathrm{H}-\mathrm{S}-20$; Table 2). However, $3 \mathrm{~d}$ at $20^{\circ} \mathrm{C}$ following storage of nonheated fruit resulted in a 2-or 3-fold increase in viscosity of the CWM whether fruit were poststorage heat-treated $(S-H-20)$ or not $(S-20)$. Similarly, swelling of the CWM was unaffected by poststorage HT, but, where fruit were heat-treated before storage, CWM swelling was reduced. Although the fruit were softer than normally ripened fruit, nonheated fruit subjected to storage $(S-20)$ had CWM that was less viscous and swelled less than that of normally ripened fruit $(20-R)$.

Trends observed in the earlier study (Grant et al., 1992) were confirmed, where CWM viscosity increased more with normal ripening $(20-R)$ than in injured fruit after storage $(S-20)$, and the results paralleled those for normally ripened kiwifruit (Redgwell et al., 1992; Redgwell and Percy, 1992).

Results with kiwifruit (Redgwell et al., 1992; Redgwell and Percy, 1992) have indicated that CWM swelling and increase in viscosity in vitro correlates with increased solubilization of pectins. This result also has been true for persimmon in this paper. However, temperature has affected the relative responses of CWM swelling, CWM viscosity, and polyuronide release. HT affected the viscosity of the released polyuronide. Storage promoted polyuronide release but prevented cell wall swelling. Viscosity of the CWM and the released polyuronide also increased during storage, and, from the size profiles, it appears that storage also inhibits degradation of the polymers. These results may be specific to one polyuronide or to a mixture of polyuronides and/or other polymers. Conversely, HT prevents solubilization of polyuronide but promotes degradation of polyuronides that are already released. The relative viscosity of the CWM depends on when the HT is applied - if heat is applied before storage, it remains nonviscous, but, if applied after storage, the increased viscosity parallels that of normal ripening and nonheated, injured fruit $(S-20)$, although slightly impeded.

Prevention of nondegradable polyuronide release during storage appears to be the process most closely correlated with development of CI symptoms. The degree of injury also was associated with an increased arabinose/xylose : glucose ratio in the solubilized polyuronide fraction [2.0 for injured fruit $(S-20, S-H-20) ; 1.2$ for partially injured fruit $(H-S-20)$, compared to values below 1.0 for harvested and stored fruit $(S)$; and 0.7 for normally ripened fruit $(20-R)]$. The results of Grant et al. (1992), Klein et al. (1990), and Luza et al. (1992) indicate that solubilization of pectin is part of the undesirable chilling response. Conversely, Mitcham and McDonald (1992) demonstrated that HT of tomato (Lycopersicon esculatum, Mill.) resulted in reduction of pectin solubilization. We also have shown that HT reduced CI, and its concomitant pectin solubilization. Thicker cell walls also were a feature of the low-temperature response in CI development in peaches [Prunus persica (L.) Batsch] (Luza et al., 1992) and an accumulation of jelly-like pectins in the intercellular spaces, perhaps not unlike the release of a high viscosity polyuronide in our experiments.

In summary, release of polyuronide from the cell wall and lack of subsequent degradation is closely associated with development of CI. However, it is currently unknown whether the release of a specific polymer is the most important feature of the chilling response or if there are a mixture of polymers-not only pectic polymers but hemicellulosic polymers as well. Thus, HT allowed us to identify the importance of the release and size of the polyuronides in the development of CI.

\section{Literature Cited}

Blumenkrantz, N. and G. Asboe-Hansen. 1973. New method for quantitative determination of uronic acids. Anal. Biochem. 54:484-489.

Bradford, M.M. 1976. A rapid and sensitive method for the quantification of microgram quantities of protein utilising the principle of protein-dye binding. Anal. Biochem. 72:248-254.

Clark, C.J. and S.K. Forbes. 1994. Nuclear magnetic resonance imaging of the development of chilling injury in 'Fuyu' persimmon (Diospyros kaki). N.Z. J. Crop Hort. Sci. 22:209-215.

Clark, C.J. and J.S. MacFall. 1996. Relaxation changes in persimmon (Diospyros kaki) stored at low temperature and modified atmosphere observed by magnetic resonance imaging. Postharvest Biol. Tech. 9:97108.

Grant, T.M., E.A. MacRae, and R.J. Redgwell. 1992. Effect of chilling on physicochemical properties of persimmon cell walls. Phytochemistry 31:3739-3744.

Harker, F.R., M.G.H. Stec, I.C. Hallett, and C.L. Bennett. 1997. Texture of parenchymatous plant tissue: A comparison between tensile and other instrumental and sensory measurements of tissue strength and juiciness. Postharvest Biol. Tech. 11:63-72.

Klein, J.D., S. Lurie, R. Ben-Arie. 1990. Quality and cell wall components of 'Anna' and 'Granny Smith' apples treated with heat, calcium, and ethylene. J. Amer. Soc. Hort. Sci. 115:954-958.

Luza, J.G., R. van Gorsel, V.S. Polito, and A.A. Kader. 1992. Chilling injury in peaches: A cytochemical and ultrastructural cell wall study. $J$. Amer. Soc. Hort. Sci. 117:114-118.

MacRae E. A. 1987. Development of chilling injury in New Zealand grown 'Fuyu' persimmon during storage. NZ. J. Expt. Agr. 15:333-344.

McGuire, R.G. 1992. Reporting of objective color measurements. HortScience 27:1254-1255.

Mitcham, E.J. and R.E. McDonald. 1992. Effect of high temperature on cell wall modifications associated with tomato fruit ripening. Postharvest Biol. Tech. 1:257-264.

Redgwell, R.J. and A.E. Percy. 1992. Cell wall changes during on-vine softening of kiwifruit. N.Z. J. Crop Hort. Sci. 20:453-456.

Redgwell, R.J., L.D. Melton, D.J. Brasch. 1992. Cell wall dissolution in ripening kiwifruit: solubilization of pectic polymers. Plant Physiol. 98:71-81.

Woolf, A.B., C.B. Watkins, J.H. Bowen, M. Lay-Yee, J.H. Maindonald, and I.B. Ferguson. 1995. Reducing external chilling injury in stored 'Hass' avocados with dry heat treatments. J. Amer. Soc. Hort. Sci. 120:1050-1056.

Woolf, A.B., S. Ball, K.J. Spooner, M. Lay-Yee, I.B. Ferguson, C.B. Watkins, A. Gunson, and S.K. Forbes. 1997. Reduction of chilling injury in the sweet persimmon 'Fuyu' by hot air heat treatments. Postharvest Biol. Tech. 11:155-164. 